RU Когнитивно-культурологические характеристики концепта ТРУДОВАЯ ДЕЯТЕЛЬНОСТЬ (на материале греческого языка)

\author{
Мирошниченко Л. Н., Фоменко Л. Н.
}

\begin{abstract}
Аннотация. Цель исследования - определить когнитивно-культурологические характеристики концепта ТРУДОВАЯ ДЕЯТЕЛЬНОСТЬ в пословицах и поговорках греческого народа. Исследование направлено на изучение структуры и принципов организации знаний о труде в единицах греческого паремиологического фонда. Научная новизна заключается в проведении целостного многоаспектного анализа составляющих данного концепта в греческих паремиях и выявлении его культурнолингвистических характеристик. В результате когнитивно-культурологического анализа когниотипа определяется культурологическая значимость составляющих системы знаний о труде в греческих паремиях, выявляются особенности картины мира греческого этноса.
\end{abstract}

\title{
Cognitive-Cultural Characteristics of the Concept LABOUR ACTIVITY (by the Material of the Greek Language)
}

\author{
Miroshnichenko L. N., Fomenko L. N. \\ Abstract. The paper aims to reveal cognitive-cultural characteristics of the concept LABOUR ACTIVITY \\ by the material of the Greek paroemias. The article analyses representation of knowledge on labour in pa- \\ roemiological units of the Greek language. Scientific originality of the study lies in the fact that the authors \\ provide a comprehensive multi-aspect analysis of the mentioned concept in the Greek paroemias, identify \\ its cultural and linguistic characteristics. As a result of the cognitive-culturological analysis, the researchers \\ determine cultural value of the concept under study, reveal specificity of the traditional Greek worldview.
}

\section{Введение}

Исследование посвящено проблеме концептуализации фрагмента действительности, определяемого понятием «трудовая деятельность» в греческой лингвокультуре.

Актуальность работы обусловлена необходимостью исследовать широкий спектр способов выражения когнитивных знаний, культурных ценностей, чувств и эмоций представителей греческого этноса; малоизученностью данного концепта в греческой лингвокультуре.

Задачи исследования: 1) формирование банка пословиц и поговорок, соотносимых с концептом ТРУДОВАЯ ДЕЯТЕЛЬНОСТЬ (решение данной задачи позволяет определить комплекс паремий для построения когниотипа); 2) построение когниотипа «трудовая деятельность» (задача направлена на получение на материале пословиц и поговорок иерархически организованной когнитивной структуры, ментально-лингвистического фрейма (когниотипа)); 3) лингвокультурологический анализ построенного когниотипа (задача предполагает определение культурологической значимости составляющих когниотипа, выявление его основных черт, особенностей).

Объектом изучения являются паремии, концептуализирующие понятие «трудовая деятельность» в греческом языке. В качестве предмета исследования рассматриваются семантические и прагматические характеристики анализируемого концепта.

Методы исследования: метод сплошной выборки - при сборе лингвистического материала; когнитивное моделирование - при построении когниотипа; интерпретативный анализ, метод количественного анализа и интроспекция - при анализе построенного когниотипа.

Теоретическая база работы - фундаментальные концепции отечественных и зарубежных лингвокультурологов и специалистов в области теории языка: А. П. Бабушкина [1], А. Соломоника [7], Ю. С. Степанова [8], В. Н. Телии [9], Ч. Филлмора [11], М. Минского [12], Э. Рош [13] и др. 
Практическая значимость работы заключается в возможности ее использования в вузовских курсах лингвокультурологии, фразеологии и паремиологии, а также в спецкурсах, посвященных вопросам когнитивной лингвистики, этнолингвистики, межкультурной коммуникации. Особая ценность работы обусловлена тем, что она представляет собой одну из редких попыток концептуализации реальности в греческом языке, а также комплексного исследования греческого паремиологического фонда.

\section{Основная часть}

Концептуализации реальности происходит средствами языка [1, с. 95]. Концепт, с одной стороны, - это способ существования культуры в ментальном мире человека. С другой - средство вхождения в культуру, а иногда влияния на нее [8, с. 11]. Концепт - ментальная структура, которая детерминируется культурой и опредмечивается в языке [6, с. 9]. Язык - одно из средств исследования стоящих за ним ментальных структур [10, с. 6].

Непременным этапом моделирования структуры концепта и систематизации его наполнения является когнитивная интерпретация, т.е. ментальная обработка результатов описания значений языковых единиц, формирующих концепт, для определения и вербализации когнитивных признаков, репрезентируемых значениями этих языковых единиц [4, с. 200].

Ментально-лингвистический фрейм (когниотип) мы рассматриваем, с одной стороны, как способ организации концепта, а с другой - как объяснительную конструкцию, необходимую для его описания. Фрейм - связанная совокупность элементов. Как когнитивная структура, он отражает способы систематизации информации в сознании человека. Количественный анализ вербализованных ментальных составляющих иерархически организованного фрейма обладает мощным потенциалом для культурологически ориентированного исследования, является необходимым этапом определения универсальных и этноспецифичных характеристик.

Когниотип структурируется как гиперфрейм, объединяющий ментально-лингвистические сущности изучаемых культур в избранной сфере [3]. Когнитивный и культурологический анализы, включающие оппозитивный и коррелятивный анализы составляющих когниотипа, обнаруживают скрытые связи между элементами фрейма и необходимы для выявления культурологической ценности параметров культурной картины мира этноса в рамках рассматриваемого концепта.

Для анализа было отобрано 1097 греческих паремий, источники отобранного языкового материала - толковые и паремиологические словари на греческом [14-18] языке.

Считаем, что подфреймы (вершинные уровни фрейма) достаточно стабильны, они отражают базовые параметры концепта. В этом мы опираемся на концепцию М. Минского [12, p. 11]. Следующим структурным элементом фрейма являются слоты. Слоты могут быть простыми или иметь развернутую структуру, детализируя свое содержание. Такая детализация отражается в когниотипе в форме вложенного фрейма. Компоненты вложенных фреймов, а также слоты репрезентируются при помощи логем. Логема представляет собой ментально-лингвистическую формулу, которая вербализует знание, структурированное во фрейм. Целые ряды паремий по своей логике и семантике могут быть объединены одной логемой [5, с. 13].

С целью обнаружения культурологической значимости выявленных составляющих фрейма и определения национально-специфических особенностей концепта ТРУДОВАЯ ДЕЯТЕЛЬНОСТЬ в греческой лингвокультуре проводится лингвокультурологический анализ построенного когниотипа. Его структура включает 30 подфреймов и 282 слота, которые дополняются 350 вложенными фреймами. Логемы, их 981, обозначают как слоты, так и элементы вложенных фреймов и служат основанием для когнитивно-культурологического анализа.

Плотность наполнения вершинных уровней когниотипа (подфреймов), т.е. объем соотносимых с каждым вершинным уровнем паремий, различна. Это имеет большое культурологическое значение. Распределив подфреймы согласно объему включенных в них паремий, мы получили когниотипическое поле с тремя зонами: ядерной, околоядерной и периферийной. К ядерной зоне относятся уровни 1-6, каждый из которых содержит более $12 \%$ паремий от общего количества, к околоядерной - уровни 7-18, содержащие от 3,5\% до $12 \%$ паремий, а к периферийной - уровни 19-30, содержащие менее 3,5\% паремий. К подфреймам ядерной зоны мы отнесли 6 вершинных уровней: Трудолюбие/Усердие, Результат/Польза, Благополучие/Благосостояние, Бездействие/Лень, Условия, Сроки/Время. В околоядерную зону вошли 12 уровней: Мастерство, Награда, Работа на себя / на другого и др. На периферии оказалось также 12 подфреймов: Место, Пьянство, Дискриминация и др.

При описании фрейма мы указываем в скобках на плотность наполнения его элементов в процентном отношении, которое рассчитывается от общего количества проанализированных греческих паремий о трудовой деятельности.

Рассмотрим в качестве примера структуру подфрейма Религия. Он относится к периферийной зоне, но подходит для иллюстрации материала в данной статье и по культурологическим параметрам, и по объему. Презентация ведется на уровне логем. Данный подфрейм представлен 9 слотами и 2 вложенными фреймами. Логемы, номинирующие слоты, следующие: 1) Чтоб достичь успеха, нужно и молиться, и работать (1,41\%); 2) Божье благословение помогает добиться результата (0,51\%); 3) Помощь Бога в работе сомнительна (0,43\%); 4) Религия с трудолюбием несовместима (0,41\%); 5) Работа - богоугодное дело, а лень - нет $(0,23 \%) ; 6)$ Трудятся во имя Бога (0,12\%); 7) Бог милосерден к ленивым (0,11\%); 8) Служение Богу - удел бедных и несчастных $(0,11 \%)$; 9) Служение Богу - тяжкий труд (0,10\%).

Вложенные фреймы в данном фрагменте когниотипа относятся к двум логемам, обозначающим слоты: 3) Помощь Бога в работе сомнительна (0,43\%); 4) Религия с трудолюбием несовместима (0,41\%). Третий слот 
детализируется вложенным фреймом из следующих подслотов: 3.1) Только молитвами результата не достигнешь (0,38\%); 3.2) Чтоб достичь результата, усердно трудись, а не молись (0,05\%); а четвертый слот - вложенным фреймом из подслотов: 4.1) Кто религиозен, тот не слишком трудолюбив (0,31\%); 4.2) Лентяи оправдываются религией (0,10\%). Из приведенного примера видно, что на уровне слотов различия выявлены и в частотности реализаций, и в наборе раскрывающих слот логем.

Остановимся на наиболее объемных составляющих когниотипа, относящихся к определенной нами ядерной зоне когниотипического поля. Они сигнализируют о высокой степени актуальности содержащихся в данных элементах фрейма знаний для изучаемой лингвокультуры. Итак, рассмотрим паремии, соотносимые с 6 вершинными уровнями: Трудолюбие (40,97\%); Результат - Польза (37,8\%); Благополучие - Благосостояние (31,66\%); Бездействие - Лень (23,34\%); Условия (16,27\%); Сроки - Время $(12,95 \%)$.

ТРУДОЛЮБИЕ (40,97\%). Трудолюбие - главное условие успеха. Стремишься к благополучию/успеху -

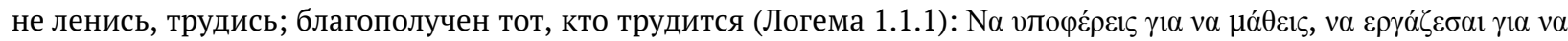
' $\chi є 1$. / Нужно стараться, чтоб научиться, нужно трудиться, чтоб приобрести (здесь и далее перевод авторов статьи. - Л. М., Л. Ф.).

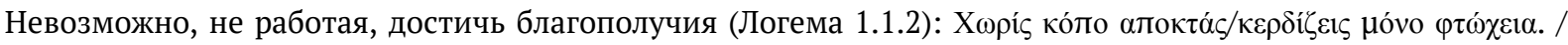
Без труда приобретаешь (выигрываешь) только бедность. Благополучия достигают трудом (Логема 1.1.4):

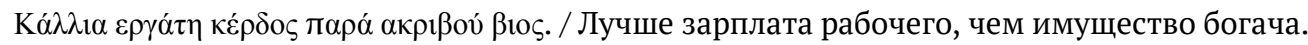

В греческих паремиях подчеркивается, что благополучия добивается тот, кто трудится, а кто ленится -

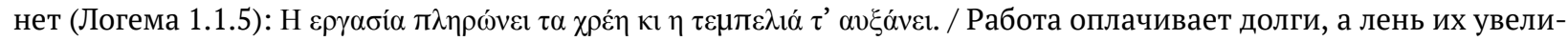

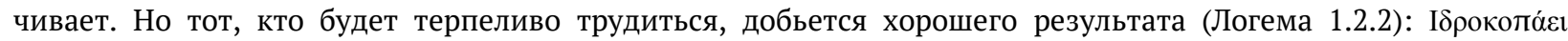

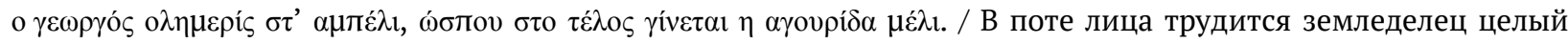
день на винограднике, пока наконец виноград созревает.

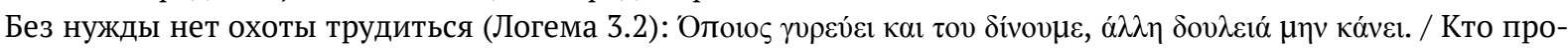
сит и получает, в работе не нуждается.

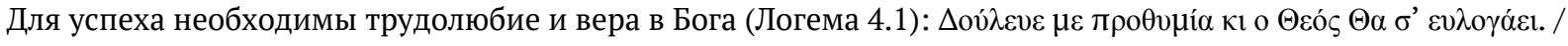
Работай с охотой, и Бог благословит.

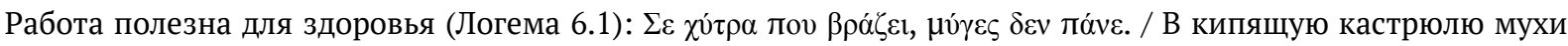

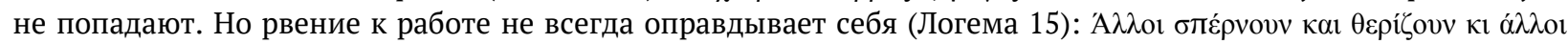

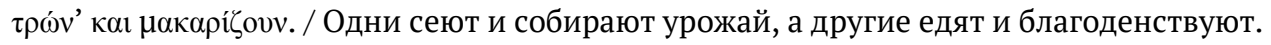

Не только от трудолюбия, но и от личных качеств и способностей человека зависят успех, благополучие

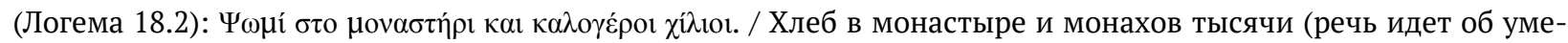

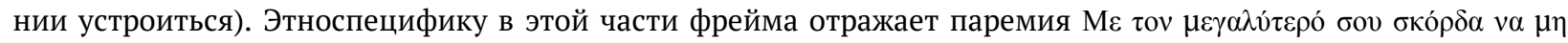

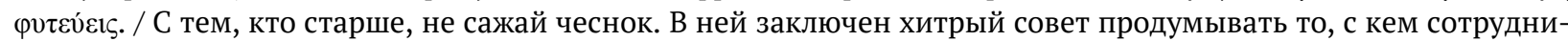
чаешь, чтоб не выполнять всю работу самому, так как пожилые, например, не нагибаются, а только указывают или выполняют легкую часть работы.

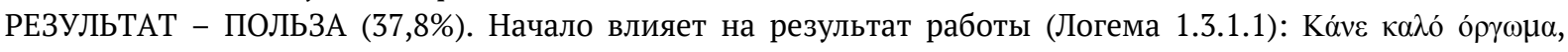

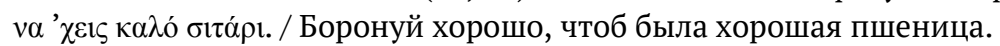

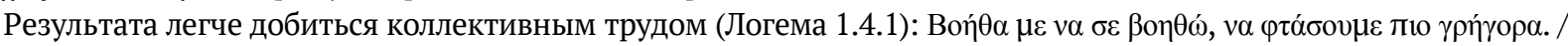
Помоги мне, и я тебе помогу быстрей дойти (до цели). А в одиночку результата не достигнешь (Логема 1.4.2):

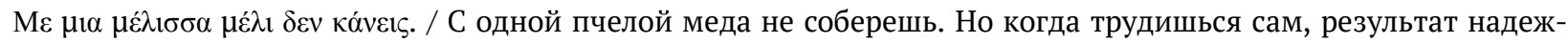

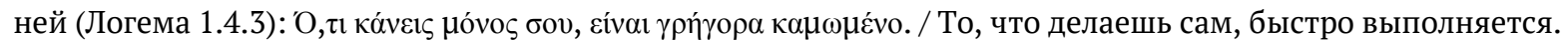

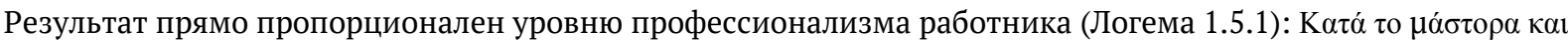

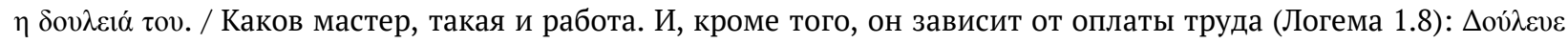

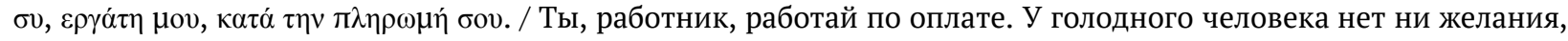
ни сил работать. То же самое происходит и с работником, который знает, что за свой труд он не получит

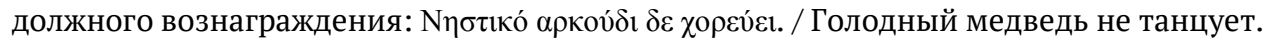

В паремиях обозначены условия, при которых не добиться результата. 1. Если лениться или делать работу

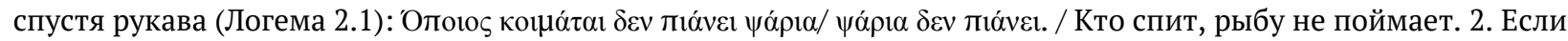

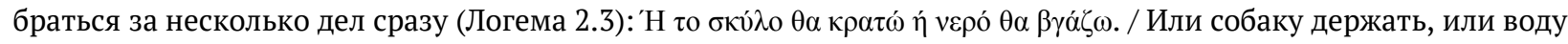

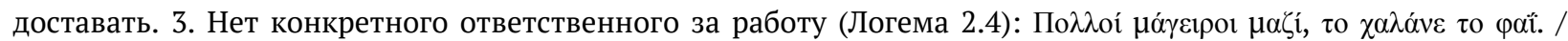

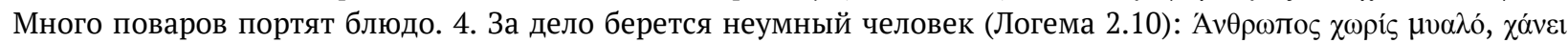
ко́ло каı бколо́. / Человек без мозгов теряет труд и цель.

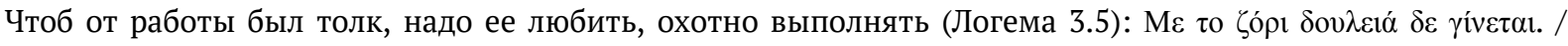
Насильно работа не выполняется.

Поспешная работа портит ее качество, но и медлительность неэффективна (Логема 4.1.2.1): Oкvó ๔ ка

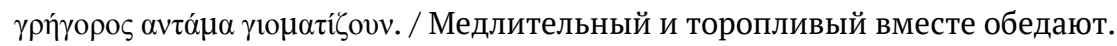

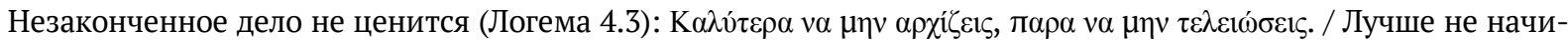

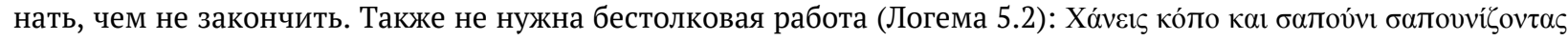
rovpoúvi. / Зря тратишь труд и мыло, намыливая поросенка. А гарантия успеха - терпеливый труд (Логема 9):

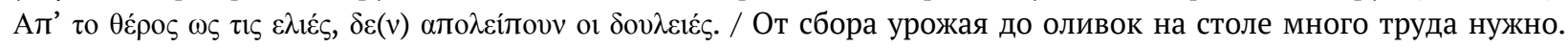

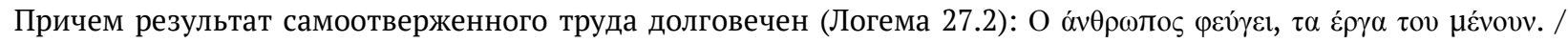
Человек уходит, а его дела (труды) остаются. 
БЛАГОПОЛУЧИЕ - БЛАГОСОСТОЯНИЕ (31,66\%). Труд, хоть и требует усилий со стороны человека, ведет к благополучию, а безделье - легкий путь, ведущий, однако, к утрате благосостояния и ухудшению положе-

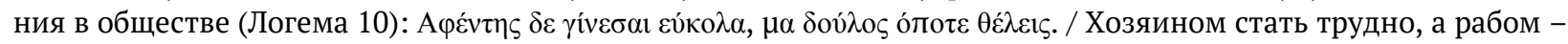
в любой момент.

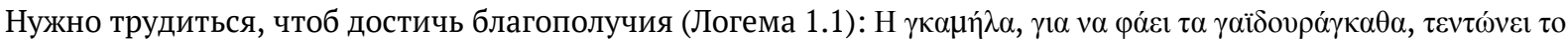

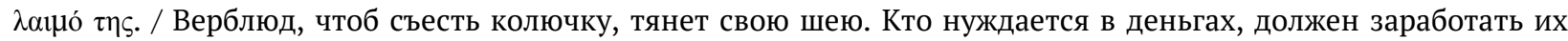

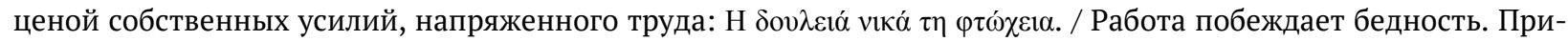

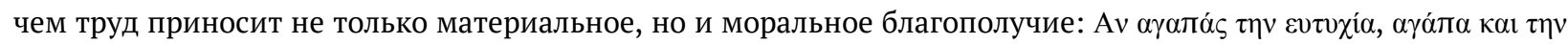

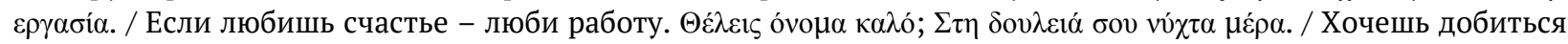
авторитета? - Работай день и ночь.

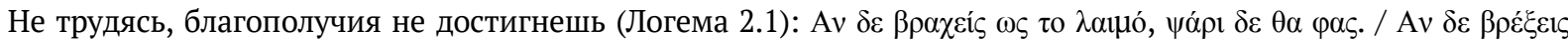

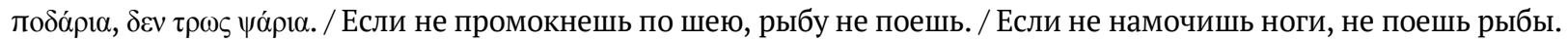

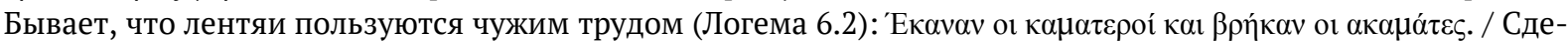
лали трудяги, а нашли бездельники.

Не надо надеяться пожить за чужой счет, надо самому добиваться собственного благополучия (Логема 13):

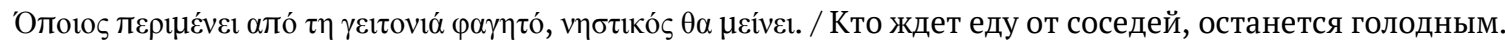

БЕЗДЕЙСТВИЕ - ЛЕНЬ (23,34\%). Греческие паремии предупреждают о том, что, ленясь, не добьешься бла-

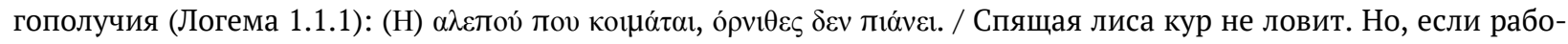

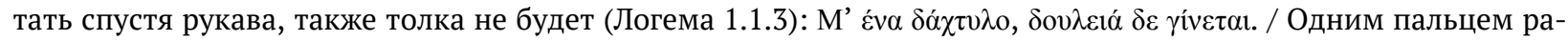
боту не сделаешь.

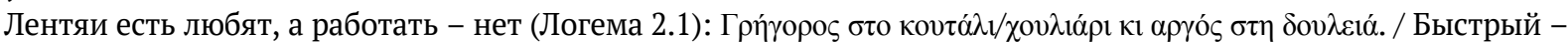
ложкой, медленный - делом.

Кто много болтает, вряд ли сумеет эффективно работать. Лентяи болтать любят, а работать - нет (Логема 2.3):

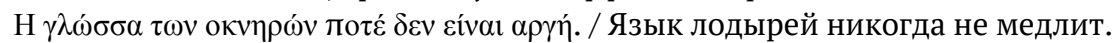

Не все трудятся с одинаковым усердием, причем в любой ситуации у тунеядца оправдание найдется (Ло-

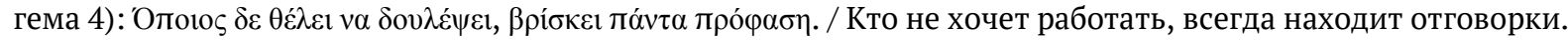

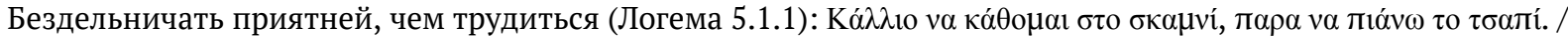
Лучше сидеть на скамье, чем держать мотыгу. Лентяй не видит греха в безделье, он находит в нем положительные стороны. Высказывается идея, что для здоровья полезней бездельничать (Логема 5.1.3): O $\alpha \delta$ оv $\lambda$ о $\delta \varepsilon$

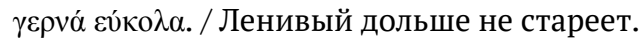

С одной стороны, безделье презентуется как наиболее эффективная жизненная позиция (Логема 5.1.4):

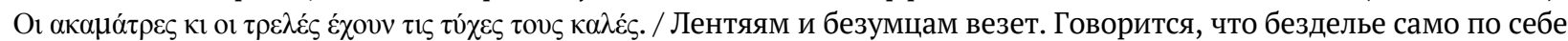
привлекательно, и, чтобы не перенапрягаться, можно даже пожертвовать благами/удобствами (Логема 7.3):

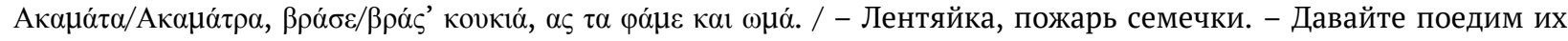

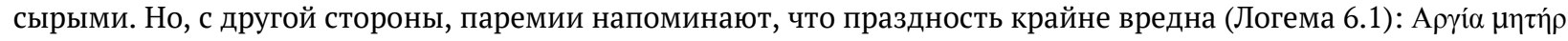

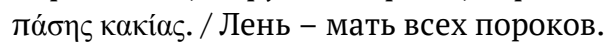

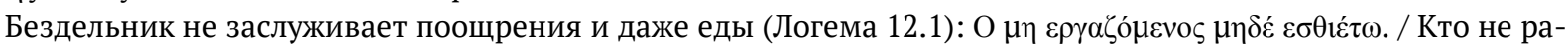

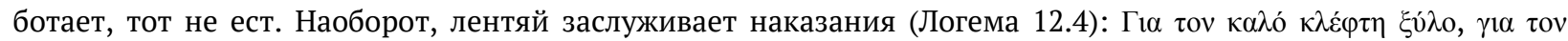

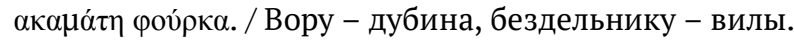

С ленью отлично справляется нужда, жизненная необходимость заставляет трудиться (Логема 13):

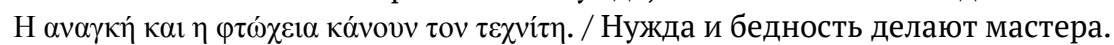

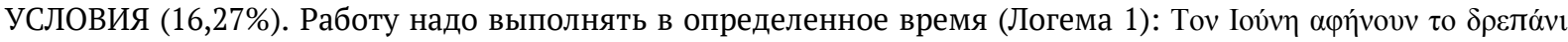

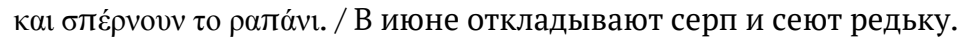

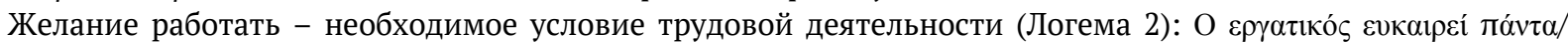

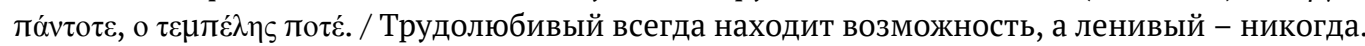

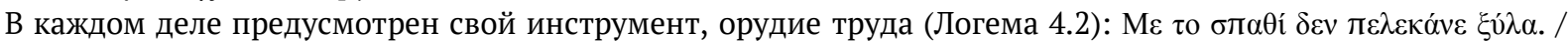
Саблей бревна не обтесывают.

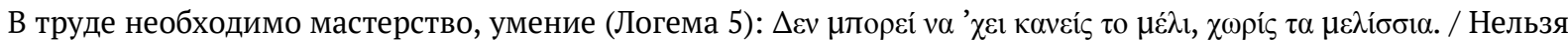

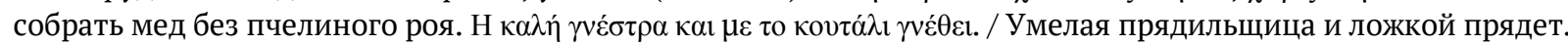

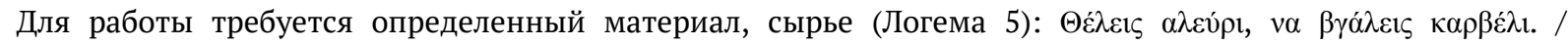
Чтоб сделать калач, нужна мука.

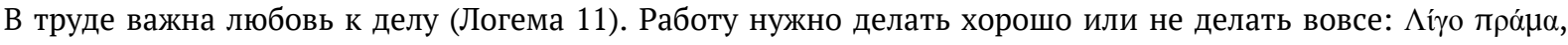

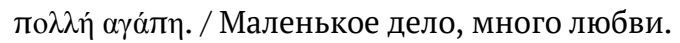

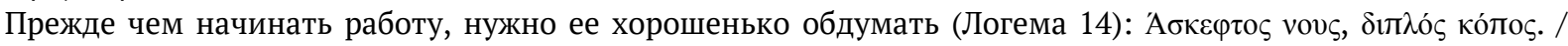
Необдуманный труд - двойная работа.

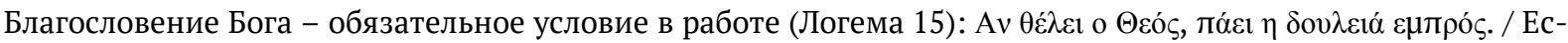

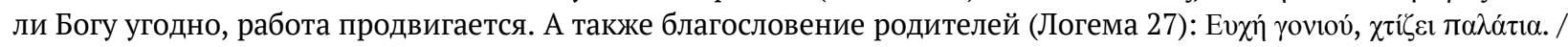
Благословение родителей дворцы строит.

Для эффективной работы требуется нормальное питание, от него зависят настроение и состояние работника. Паремии предупреждают, что трудиться, испытывая голод или жажду, невозможно (Логема 17): $\Delta \omega ́ \sigma \varepsilon$

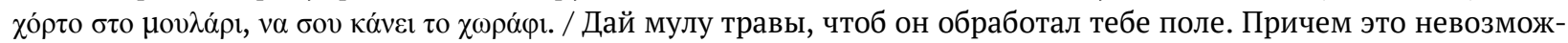

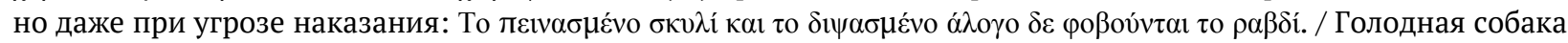
и испытывающая жажду лошадь палки не боятся. 
В греческих паремиях отмечается также, что в каждом деле нужны свои умения и условия (Логема 28):

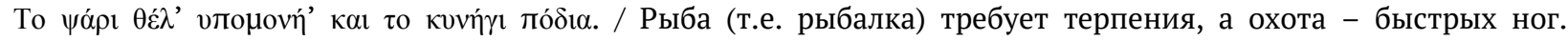

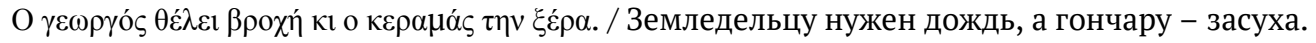

СРОКИ - ВРЕМЯ (12,95\%). В паремиях подчеркивается необходимость своевременно выполнять работу

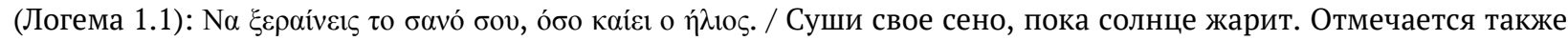

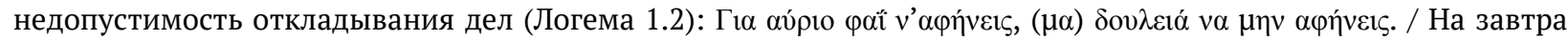
еду оставляй, а работу не оставляй.

Важно, что вовремя дело легче выполнить, чем потом наверстывать (Логема 1.4): $\Sigma \tau \eta v ~ \omega ́ \alpha ~ \tau \eta \varsigma ~ \mu 1 \alpha ~ \beta \varepsilon \lambda o v i \alpha$,

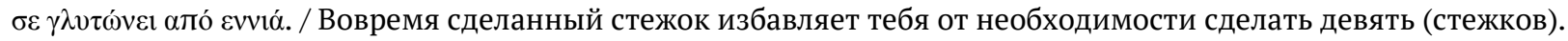

Время, затраченное на работу, связано с благополучием, успехом. Если мало времени уделяешь работе,

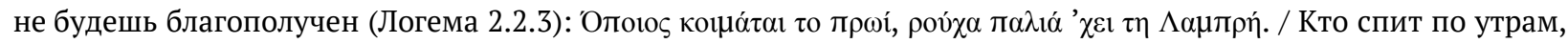
у того старая одежда на Пасху. Если работаешь вовремя, обеспечиваешь себе благополучие (Логема 4.2.1):

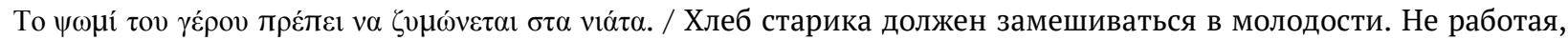

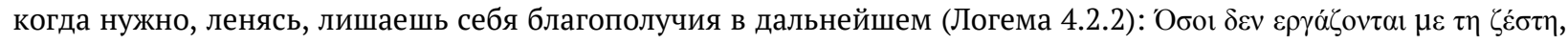

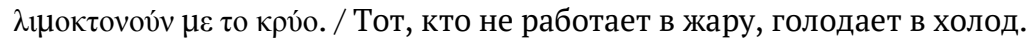

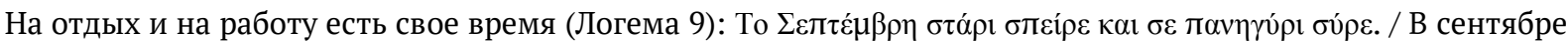
посей пшеницу, потом иди на гулянье.

\section{Заключение}

Подводя итог, должны отметить, что разница частотности обращения к элементам фрейма свидетельствует о различной культурологической значимости компонентов фрейма и отражает характерные черты греческой картины мира. В паремиях греческого языка широко представлены аспекты, связанные с понятием трудолюбия, благополучия, с результатом труда и условиями, необходимыми для осуществления трудовой деятельности, с бездельем и ленью, а также с соотношением времени и работы. Поэтому считаем обоснованным утверждать, что перечисленные феномены, аспекты, понятия и характеристики, соотносимые с рассматриваемым концептом, являются наиболее значимыми для греческой этнокультуры.

Описанные характеристики концепта ТРУДОВАЯ ДЕЯТЕЛЬНОСТЬ в греческом языке способствуют осознанию его сущности и выявлению как универсальных, так и национально-специфичных характеристик культурной картины мира греческого этноса.

В перспективе мы намерены провести сопоставительное исследование русских и греческих паремий о труде для выявления уникальных логем - «полных лакун» [2, с. 129]. Мы также планируем использовать экспериментальный метод, в частности ассоциативный эксперимент, с целью определения степени совпадения и актуальности различных моделей ассоциирования в русской и греческой культурах.

\section{Список источников}

1. Бабушкин А. П. Типы концептов в лексико-фразеологической семантике языка. Воронеж: Изд-во Воронежского государственного ун-та, 1996. 104 с.

2. Баранов А. Г., Мирошниченко Л. Н. «Значимость» и «личностный смысл» в когнитивно-культурологической модели жанра // Жанры речи: сборник научных статей. Саратов: Наука, 2007. Вып. 5. Жанр и культура. С. 123-130.

3. Мирошниченко Л. Н. Когнитивно-культурологическое представление концепта «Труд» в паремиологическом фонде русского и новогреческого языков: автореф. дисс. ... к. филол. н. Краснодар, 2007. 23 с.

4. Попова З. Д., Стернин И. А. Когнитивная лингвистика. М.: АСТ; Восток - Запад, 2007. 226 с.

5. Савенкова Л. Б. Русская паремиология: семантический и лингвокультурологический аспекты. Ростов-наДону: Изд-во Рост. ун-та, 2002. 240 с.

6. Слышкин Г. Г. От текста к символу: лингвокультурные концепты прецедентных текстов в сознании и дискурсе. М.: Academia, 2000. 128 c.

7. Соломоник А. Семиотика и лингвистика. М.: Молодая гвардия, 1995. 352 с.

8. Степанов Ю. С. Константы. Словарь русской культуры. М.: Школа «Языки русской культуры», 1997. 824 с.

9. Телия В. Н. Русская фразеология. Семантический, прагматический и лингвокультурологический аспекты. М.: Школа «Языки русской культуры», 1996. 288 с.

10. Токарев Г. В. Теоретические проблемы вербализации концепта «Труд» в русском языке: дисс. ... д. филол. н. Волгоград, 2003. 472 с.

11. Филлмор Ч. Фреймы и семантика понимания [Электронный ресурс]. URL: https://classes.ru/grammar/ 164.new-in-linguistics-23/source/worddocuments/_4.htm (дата обращения: 02.10.2020).

12. Minsky M. A framework for representing knowledge // Frame conceptions and text understanding / ed. by D. Metzing. Berlin - N. Y.: De Gruyter, 1980. P. 1-25.

13. Rosch E. Prototype classification and logical classification: The two systems // New Trends in Cognitive Representation: Challenges to Piagrt's Theory / ed. by E. Scholnick. Hillsdale, N. J.: Erlbaum, 1983. P. 73-86.

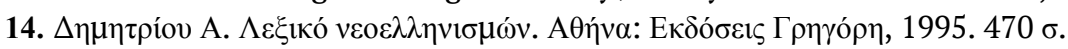




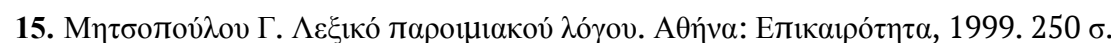

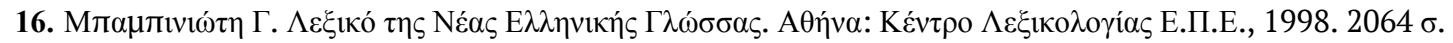

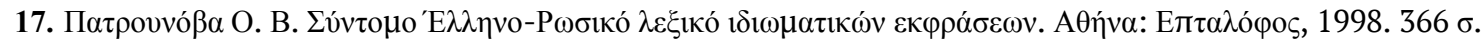

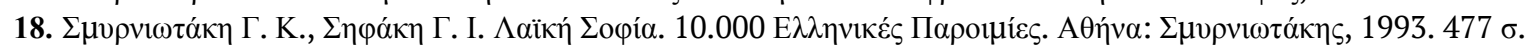

\section{Информация об авторах | Author information}

RU Мирошниченко Луиза Николаевна ${ }^{1}$, к. филол. н. Фоменко Лариса Николаевна ${ }^{2}$, к. филол. н., доц.

${ }^{1}$ Кубанский государственный университет, г. Краснодар

${ }^{2}$ Краснодарский государственный институт культуры

EN Miroshnichenko Luiza Nikolaevna ${ }^{1}, \mathrm{PhD}$

Fomenko Larisa Nikolaevna ${ }^{2}, \mathrm{PhD}$

${ }^{1}$ Kuban State University, Krasnodar

${ }^{2}$ Krasnodar State Institute of Culture

1ioussova@mail.ru, 2fomvon@mail.ru

Информация о статье | About this article

Дата поступления рукописи (received): 17.07.2020; опубликовано (published): 09.04.2021.

Ключевые слова (keywords): когниотип; представление знаний; ментально-лингвистическая сущность; фрейм; этноспецифика; cognitive type; knowledge representation; mental-linguistic essence; frame; ethnic specificity. 